\title{
Kegagalan Inovasi Pertamina dalam Mengembangkan Rantai Supply Pemasaran dan Ketergantungan Terhadap Impor BBM Produksi Kilang Minyak Singapura
}

\section{Pertamina's Innovation Failure in Developing Marketing Supply Chains and Reliance on Imported Petroleum Production from Singapore's Oil Refineries}

\author{
Ratna Dewi Wuryandari ${ }^{1}$ \\ ${ }^{1}$ Pusat Pengembangan Kebijakan, Kementerian Ketenagakerjaan Republik Indonesia \\ E-mail: ratnadewiwuryandari@gmail.com
}

\begin{abstract}
Innovation is often an important demand in supporting a breakthrough change that will have an impact on the added value of the company and the country. Through natural resource innovation, it is expected to be able to create new production resources and processing resources. However, an innovation that was initially built as a breakthrough in the end often deviates from the implementation due to a complex system and is related to the practical interests of a group of groups. This paper uses a case study of Pertamina Energy Trading Limited/Petral in the failure of innovations to develop a marketing supply chain and related to Pertamina's dependence on imported fuel from Singapore's oil refineries. The results of the research concluded that culture is the fundamental foundation in governance that underlies in various fields as well as breakthroughs made by the Government. From the failure of Pertamina through Petral, we can learn, where culture and transformational leadership are key factors that will bring about change and development of innovation in various fields in Indonesia.
\end{abstract}

Keywords: innovation, failure, petral pertamina, culture, leadership

\begin{abstract}
Abstrak
Inovasi seringkali menjadi tuntutan penting dalam mendukung sebuah terobosan perubahan yang akan berdampak pada nilai tambah perusahaan dan negara. Melalui inovasi sumber daya alam, maka diharapkan dapat menciptakan sumber daya produksi baru maupun pengolahan sumber daya. Namun demikian, sebuah inovasi yang pada awalnya dibangun sebagai terobosan pada akhirnya seringkali menyimpang pada pelaksanaan akibat system yang kompleks dan terkait dengan kepentingan praktis dari sekelompok golongan. Penulisan ini menggunakan studi kasus Pertamina Energy Trading Limited/Petral dalam kegagalan inovasi yang dilakukan untuk mengembangkan rantai supply pemasaran serta terkait ketergantungan Pertamina terhadap impor BBM produksi kilang minyak Singapura. Hasil penelusuran penulisan menyimpulkan, budaya merupakan fondasi mendasar dalam pemerintahan yang mendasari dalam berbagai bidang serta terobosan-terobosan yang dilakukan oleh Pemerintah. Dari kegagalan Pertamina melalui Petral kita dapat belajar, dimana budaya dan kepemimpinan
\end{abstract}




\section{Wuryandari: " Kegagalan Inovasi Pertamina dalam Mengembangkan Rantai Supply Pemasaran dan ..."}

transformasional merupakan factor kunci yang akan membawa perubahan dan pengembangan inovasi dalam berbagai bidang di Indonesia.

Kata Kunci : inovasi, kegagalan, petral pertamina, budaya, kepemimpinan

\section{Pendahuluan}

Inovasi seringkali dilakukan di banyak negara untuk mendukung perubahan menuju masa depan yang lebih berkelanjutan dalam pengelolaan sumber daya. Menurut Drucker (1996), Inovasi atau kebaruan dilakukan dengan menciptakan sumber daya produksi baru maupun pengolahan sumber daya yang sudah ada, dengan tujuan pertambahan nilai potensi. Namun sejauh mana sebuah inovasi dalam menciptakan sumber daya dapat diimplementasikan seringkali tunduk pada politik yang kompleks dan koalisi yang kuat di seluruh system tata Kelola dan skala kepentingan (Daniell, Coombes dan White, 2014). Sebuah inovasi yang pada awalnya dibangun untuk pengembangan dan terobosan, pada akhirnya seringkali menjadi menyimpang pada pelaksanaan akibat system yang kompleks dan terkait dengan berbagai kepentingan praktis dari sekelompok golongan (Daniell, Coombes dan White, 2014). Inovasi dapat hadir dalam berbagai bentuk yang mempengaruhi produk, proses dan model bisnis (Yip dan Mckern, 2015). Menurut Yip dan Mckern. 2015, sebuah inovasi dari perusahaan dapat memiliki 8 tipe antara lain : inovasi biaya, inovasi proses, inovasi aplikasi, inovasi rantai pasokan, inovasi produk, inovasi teknologi, inovasi model bisnis dan inovasi tidak berdasar pada pelanggan.

Tulisan ini didasari dari sebuah pengalaman dimana ketergantungan Indonesia terhadap impor Bahan Bakar Minyak dari Singapura karena Indonesia gagal membangun momentum untuk menciptakan peluang terobosan dalam pengelolaan minyak dan gas bumi karena sejumlah alasan baik dari tata kelola, kepentingan praktis sekelompok golongan maupun pengaruh lingkungan dan politik yang kompleks. Selain itu, sisi organisasi perusahaan memiliki sejumlah alasan yang dapat menyumbang kegagalan inovasi, antara lain karena perusahaan tidak efisien, tidak berkualitas, tidak cepat, tidak inovatif serta tidak pintar (Sutisna dan Huseini, 2018).

Keberhasilan Singapura membangun pusat oil-refinery membuat sebagian besar impor BBM Indonesia berasal dari negara tersebut. Bahkan Indonesia menggunakan 
MOPS (Mean of Plats Singapore) untuk menentukan harga patokan harga Bahan Bakar Minyak (BBM) dalam negeri. Akibatnya Indonesia mengalami ketergantungan BBM pada Singapura (Burmansyah dan Nasution, 2015). Ketergantungan pada impor BBM dari Singapura semakin tinggi, karena setelah berakhirnya rezim Orde Baru, pemerintah sama sekali tidak membangun kilang pegelolaan baru, sedangkan kapasitas dan teknologi kilang yang ada di dalam negeri tidak mampu dan tidak mencukupi mengelola minyak yang dihasilkan di dalam negeri. Alasanya keengganan pemerintah dan pertamina membangun kilang karena pembangunan kilang tidak terlalu menguntungkan, sedangkan biaya pembangunan kilang terbilang tidak kecil (Burmansyah dan Nasution, 2015). Meskipun tidak memiliki sumur minyak, Singapura lebih maju dalam hal kepemilikan kilang minyak. Saat ini ada tiga kilang besar yang beroperasi di Singapura yaitu ExxonMobil Jurong Island Refinery (kapasitas 605.000 barel/hari), SRC Jurong Island Refinery (290.000 barel/hari), dan Shell Pulau Bukom Refinery (500.000 barel/hari) (sumber: https://www.cnbcindonesia.com/). Dengan kebutuhan domestik yang minim (populasi Singapura kurang lebih 5,7 juta), Singapura memiliki kapasitas untuk menjadi pemasok energi bagi negara-negara di kawasan asia tenggara. Di sisi lain, Singapura merupakan negara importir terbesar minyak mentah asal Indonesia. Pada Januari-September 2019, nilai ekspor minyak mentah Indonesia ke Singapura adalah US\$ 546,71 juta. Nilai ini mencapai 43,49\% dari total ekspor minyak mentah Indonesia (https://www.cnbcindonesia.com/).

Melihat dari sejarah, Pemerintah Indonesia melalui Pertamina pernah berusaha untuk melakukan pemasaran produk ke pasar dunia secara lebih efisien di Pusat Trading Singapura. Pemasaran produk minyak dan gas bumi dilakukan Pertamina di Singapura karena Singapura merupakan merupakan pusat perdagangan minyak dan produk minyak dunia sehingga aksesnya lebih mudah. Dalam melakukan terobosan inovasi tersebut, pada tahun 1969, Pertamina dan satu "interest group" Amerika Serikat mendirikan Perta Group dengan tujuan memasarkan minyak mentah dan produk minyak Pertamina di pasar Amerika Serikat. Perta Group-yang memulai kegiatan perdagangan minyak pada tahun 1972-terdiri dari Perta Oil Marketing Corporation Limited, perusahaan Bahama yang berkantor di Hong Kong, dan Perta Oil Marketing Corporation, perusahaan California yang menjalankan aktivitas keseharian di Amerika Serikat. Pada 1978 terjadi reorganisasi besar-besaran. Perusahaan yang berbasis di Bahama digantikan dengan Perta Oil 


\section{Wuryandari: " Kegagalan Inovasi Pertamina dalam Mengembangkan Rantai Supply Pemasaran dan ..."}

Marketing Limited, perusahaan yang berbasis di Hong Kong. Pada September 1998, Pertamina mengambil alih seluruh saham Perta Group. Pada Maret 2001, atas persetujuan pemegang saham, perusahaan berubah nama menjadi Pertamina Energy Trading Limited (PETRAL) yang berperan sebagai trading and marketing arm Pertamina di pasar internasional (Tim Reformasi Tata Kelola Minyak dan gas Bumi Nasional, 2015).

Petral mendirikan anak perusahaan berbadan hukum dan berkedudukan di Singapura bernama Pertamina Energy Services Pte Limited (PES) pada 1992 yang dibebani tugas melakukan perdagangan minyak mentah, produk minyak, dan petrokimia. Pembentukan dan operasional Perta Group pada awalnya lebih diarahkan untuk pemasaran minyak bumi mengingat di masa itu Indonesia merupakan pengekspor neto (net exporter) minyak bumi dan masih menjadi anggota OPEC. Peranan minyak bumi juga masih sangat dominan saat itu baik sebagai sumber penerimaan devisa maupun sebagai sumber penerimaan negara dalam Anggaran Pendapatan dan Belanja Negara (APBN). Namun demikian, sejak 1998, produksi minyak bumi terus menurun sementara konsumsi meningkat tajam. Sejak 2003, konsumsi minyak dan produk minyak di dalam negeri sudah melebihi produksinya (Tim Reformasi Tata Kelola Minyak dan gas Bumi Nasional, 2015).

Pada tanggal 22 Desember 2015, Presiden Joko Widodo menandatangani Peraturan Presiden Nomor 146 Tahun 2015 tentang Pelaksanaan Pembangunan dan Pengembangan Kilang Minyak di Dalam Negeri. Langkah ini diambil untuk menghindari defisit bahan bakar minyak. Pemerintah mengumumkan pembubaran Petral (Pertamina Energy Trading Limited) pada 13 Mei 2015. Langkah ini membuat Pertamina bisa menghemat hingga USD 22 juta pada 2015. (https://economy.okezone.com/2018). Pembubaran Petral (Pertamina Energy Trading Limited) tersebut dikeluarkan dengan mempertimbangkan hasil dari Tim Reformasi Tata Kelola Minyak dan Gas Bumi (Migas) yang dibentuk oleh Menteri Energi dan Sumber Daya Mineral (ESDM) Sudirman Said pada 16 November 2014. Tim Reformasi yang diketuai oleh Faisal Basri mengeluarkan 12 rekomendasi dan salah satu yang harus digarisbawahi adalah melakukan audit forensik agar segala proses yang terjadi di Petral/PES menjadi jelas. Audit forensik dilakukan oleh institusi audit yang kompeten di Indonesia dan memiliki jangkauan kerja ke Singapura serta negara terkait lainnya. Hasil audit forensik tersebut dapat dijadikan sebagai pintu masuk membongkar potensi pidana, khususnya membongkar praktek mafia migas. 
Selama beberapa tahun terakhir dari hasil rekomendasi Tim Reformasi Tata Kelola Migas tersebut, muncul ketidakpercayaan masyarakat terhadap Petral/PES dalam menjalankan fungsinya sebagai anak perusahaan negara yang ditunjuk untuk melakukan perdagangan minyak mentah dan produk minyak, khususnya dalam pengadaan BBM yang dari waktu ke waktu semakin meningkat cukup tajam. Peran Petral/PES selama ini dipandang belum dapat memenuhi tuntutan efisiensi dalam pengadaan minyak mentah dan BBM. PES dianggap cukup hanya berperan sebagai trading arms atau buying agent Pertamina dan tidak perlu berkembang menjadi trading company karena dipandang akan membahayakan keamanan pasokan minyak (supply security) (Tim Reformasi Tata Kelola Minyak dan gas Bumi Nasional, 2015). Sebelum tahun 2003, defisit perdagangan bahan bakar minyak (BBM) masih dapat ditutupi oleh surplus perdagangan minyak mentah. Namun, setelah itu, defisit BBM tidak lagi dapat ditutupi oleh surplus minyak mentah, sehingga sejak tahun 2013, transaksi perdagangan minyak mentah mulai mengalami defisit (Tim Reformasi Tata Kelola Minyak dan gas Bumi Nasional, 2015). Perubahan status Indonesia dari eksportir neto menjadi importir neto ternyata tidak mengubah peran Petral dengan PES sebagai anak perusahaan tetap sebagai trading arms dengan tambahan fungsi sebagai agen pengadaan minyak bumi dan BBM. Mengingat kebutuhan BBM Indonesia yang relative sangat besar dan PES merupakan satu-satunya pihak yang ditunjuk sebagai penjual dan pembeli minyak mentah dan BBM, volume usaha PES semakin membesar (Tim Reformasi Tata Kelola Minyak dan gas Bumi Nasional, 2015). Peranan Petral akhirnya digunakan oleh Mafia Migas untuk memburu rente dari monopoli Petral dalam impor BBM (https://www.cnbcindonesia.com/news/2019). Modus pemburuan rente dilakukan dalam bidding dan blending penyediaan impor BBM yang dilakukan secara daring dimana pemenang tender selalu dari negara-negara bukan penghasil minyak. Pemenang tender tersebut kemudian digunakan oleh Mafia Migas sebagai frontier untuk memasok BBM dengan harga mark up, selanjutnya harga BBM yang mahal dibeli oleh Pertamina dan dijual di pasar dalam negeri dengan memberikan subsidi yang dialokasikan dari APBN (https://www.cnbcindonesia.com/news/2019).

Penulisan ini dilakukan untuk menelaah bagaimana sebuah inovasi yang pada awalnya diciptakan untuk mendukung perubahan yang lebih baik namun justru kehilangan arah karena proses inovasi yang di pengaruhi oleh politisasi yang kuat dan kepentingan pada sekelompok golongan yang mempengaruhi pada hampir seluruh 


\section{Wuryandari: " Kegagalan Inovasi Pertamina dalam Mengembangkan Rantai Supply Pemasaran dan ..."}

kegiatan bisnis. Belajar dari kegagalan kasus Petral (Pertamina Energy Trading Limited) dalam kasus ini dianalisis karena tidak berjalannya factor pendorong dalam pengembangan inovasi.

\section{Tujuan}

Berdasarkan latar belakang yang telah disampaikan di atas, maka tujuan dari penulisan ini adalah menelaah bagaimana kegagalan Pertamina dalam mengembangkan inovasi pengembangan usaha terhadap pemasaran produk-produknya melalui anak perusahaan yaitu Pertamina Energy Trading Limited (Petral) yang berperan sebagai trading and marketing arm Pertamina di pasar internasional. Dari kegagalan kasus Pertamina tersebut, selanjutnya diidentifikasi dan di analisis untuk pembelajaran bagi Indonesia sehingga diharapkan tidak terjadi kegagalan dalam pengembangan inovasi untuk masa selanjutnya.

\section{Metode}

Metoda pengumpulan data yang digunakan dalam penulisan ini adalah desk research, dimana data dan informasi diperoleh melalui studi kepustakaan dari berbagai macam sumber antara lain: buku, karya ilmiah, internet dan lain sebagainya. Metode analisis penulisan dilakukan secara kualitatif melalui membandingkan antara fakta yang terjadi di lapangan dengan berbagai literatur dan teori yang relevan.

\section{Pembahasan}

Inovasi penting di sektor sumber daya alam. Sumber daya alam khususnya minyak dan gas bumi mengalami tekanan yang semakin meningkat karena sejumlah faktor, termasuk pertumbuhan populasi, perubahan pola konsumsi, polusi dan degradasi lingkungan, warisan infrastruktur, peningkatan konsumi bahan bakar minyak dan gas, kurangnya pengelolaan yang terkoordinasi, serta variabilitas dan perubahan iklim. Migas merupakan sumber daya alam tidak terbarukan (non-renewable resources). Cadangan minyak dan gas akan berkurang sejalan dengan aktivitas eksploitasi dan hanya akan bertambah jika penemuan cadangan baru lebih banyak ketimbang yang dieksploitasi. Sementara penemuan cadangan baru yang terjadi melalui kegiatan eksplorasi memerlukan biaya besar. Eksplorasi dan ekspoitasi migas merupakan kegiatan usaha yang berdimensi jangka Panjang, memerlukan investasi besar dengan resiko pada sisi 
keuangan, teknis dan operasional sangat tinggi. Seiring dengan semakin meningkatnya populasi penduduk dan terus meningkatnya jumlah permintaan bahan bakar minyak dan gas, pendirian Petral dilakukan untuk mendorong supply chain pertamina lebih baik serta mendorong rantai pasokan produksi minyak mentah Indonesia di pasar dunia. Hal ini dilakukan oleh Pemerintah karena pada saat itu produksi dari kilang minyak Indonesia masih cukup surplus. Dari segi jenis inovasi, Pertamina telah melakukan tahapan awal dalam meningkatkan pemasaran minyak mentah dan produk minyak dalam rangka meningkatkan pendapatan dan mendorong rantai pasokan yang lebih baik dan pemasaran yang lebih efisien, dengan melakukan inovasi model bisnisnya. Dimana dari sebelumnya lebih memfokuskan pada memproduksi minyak mentah, dan kemudian melakukan perubahan pada elemen model bisnis untuk menghasilkan cara baru dalam meningkatkan pendapatan perusahaan. Yip dan Mckern (2015), membagi jenis inovasi terdiri dari inovasi produk dimana terjadi ketika produk atau jasa memiliki fitur bernilai bagi pelanggan yang baru kepada dunia atau suatu negara; inovasi teknologi, yaitu inovasi yang dilakukan dengan menghasilkan inovasi teknologi tinggi dengan signifikansi global ataupun menunjukkan kemampuan untuk menggunakan teknologi kelas dunia untuk menciptakan inovasi; inovasi model bisnis dimana perubahan pada satu atau lebih elemen model bisnis menghasilkan cara baru untuk melakukan bisnis serta inovasi tidak berdasar pada pelanggan yang terjadi ketika bisnis dapat melayani segmen pelanggan yang sebelumnya tidak dilayani dalam kategori tertentu, contohnya Apple ipad.

Inovasi memiliki factor pendorong yang dapat membuat inovasi yang dilakukan oleh perusahaan sukses memasuki pasar yang besar dan dinamis. Yip dan Mckern (2015), dalam menggambarkan kesuksesan inovasi di China menjelaskan ada 4 faktor pendorong inovasi di China agar sebuah inovasi dapat sukses dalam melewati tahapan dalam fase pengembangan inovasi. Yip dan Mckern (2015), menjelaskan variabel yang mendasari 4 faktor pendorong inovasi di China di sebut dengan model Four Cs. Faktor pertama Customers, merupakan faktor utama dimana perusahaan Cina menggunakan setiap mode inovasi untuk memenuhi kebutuhan yang dirasakan pelanggan; dan kedua, mereka lebih fokus pada kebutuhan pelanggan dari perusahaan multinasional yang beroperasi di Cina. Menurut Yip dan Mckern (2015), pemahaman perusahaan China tentang pelanggan telah berevolusi, seiring dengan kapasitas inovatif mereka, dari imitasi menjadi "fit to purpose" dan kemudian ke standar dunia. Faktor kedua, Culture, termasuk kepemimpinan dan 


\section{Wuryandari: " Kegagalan Inovasi Pertamina dalam Mengembangkan Rantai Supply Pemasaran dan ..."}

dorongan kewirausahaan. Ini terbukti pada sebagian besar kasus perusahaan Cina yang sukses seperti Huawei, TV TCL, Xiaomi dan sebagainya. Penggunaan istilah Culture dalam kerangka kerja Empat Cs ini lebih luas dibandingkan mengenai istilah budaya sebuah bangsa. Culture Ini juga termasuk ambisi pemerintah Cina untuk menjadi negara yang berpengaruh di dunia, termasuk tekadnya untuk menciptakan lingkungan inovasi kelas dunia. Perusahaan Cina lebih bersedia untuk bermitra dengan perusahaan lokal daripada perusahaan multinasional untuk membantu membuat local dapat melewati lompatan ke fase berikutnya - yaitu, dari sumber daya baru ke pasar baru. Dalam buku Yip dan Mackern (2015), Pemerintah Cina, terlepas dari komitmennya kepada Organisasi Perdagangan Dunia, mendukung membantu perusahaan lokal untuk menjadi sukses di pasar lokal sehingga dapat mengembangkan Capabilities dan Cash untuk berhasil di pasar negara lain. Ketika fokus bergeser dari sumber daya baru ke pasar baru, perusahaan milik negara cenderung mengembangkan proses manajemen, budaya, atau kemampuan internal yang mereka perlukan untuk memasuki pasar inovasi yang lebih intensif. Perusahaan swasta, seperti yang ditunjukkan Yip dan Mckern mengembangkan kemampuan yang dibutuhkan, terutama pemahaman yang diperlukan pelanggan. Dan di mana perusahaan lokal tidak memiliki kemampuan, seperti merek atau teknologi, mereka memiliki cash untuk mendapatkannya dari Pemerintah. Dalam menggambarkan empat faktor yang menentukan kapasitas inovatif Cina dalam buku Yip dan Mckern (2015), tampak bagaimana keempat faktor tersebut (Customers, Culture, Capabilities dan Cash) telah memengaruhi pertumbuhan perusahaan-perusahaan Cina. Keempat faktor tersebut kemudian berinteraksi untuk menjelaskan pengembangan kapasitas inovatif selama tiga fase pembangunan.

Keempat faktor tidak berfungsi secara independent untuk menguraikan interaksi antara elemen-elemen yang mendasarinya. Yip dan Mckern menjelaskan keempat faktor tersebut menunjukkan cara sederhana untuk melihat pendorong yang telah berkontribusi terhadap lonjakan inovasi yang telah terjadi di China.

Keempat factor pendorong inovasi tersebut, untuk menganalisis bagaimana inovasi sebuah perusahaan dapat berkembang dan sukses menembus pasar di China, Yip dan McKern (2015), menganalisis dengan melihat keempat factor pendorong inovasi (Four Cs) yang digabungkan dengan fase perkembangan inovasi dimana sebuah perusahaan dalam melakukan inovasi juga harus memperhatikan peran dari Four Cs 
dalam tahapan perkembangan inovasi. Peranan 4 faktor pendorong dalam fase perkembangan inovasi menjadi kesuksesan sebuah perusahaan di China dalam mengantisipasi terhadap kegagalan inovasi karena telah melewati seluruh fase perkembangan dari menjadikan prioritas utama dalam fase perkembangan menjadikan orchestra keempat factor pendorong dalam tahapan inovasi. Gambar berikut merupakan gambaran dimana 4 faktor pendorong yang kemudian memainkan peranannya dalam setiap fase tahapan perkembangan inovasi.

\begin{tabular}{|c|c|c|}
\hline Coustumer & $\begin{array}{l}\text { Fase 1: Pemahaman } \\
\text { pelanggan/pasar }\end{array}$ & \\
\hline Culture & $\begin{array}{l}\text { Fase 2: Enterpreneur, } \\
\text { Ambisi kemandirian } \\
\text { teknologi }\end{array}$ & $\begin{array}{l}\text { Ekosistem Inovatif } \\
\text { Makro }\end{array}$ \\
\hline Capabilities & \multirow{2}{*}{$\begin{array}{l}\text { Fase 3: Transisi dari } \\
\text { mencari sumberdaya } \\
\text { baru - mencari } \\
\text { pengetahuan baru }\end{array}$} & \multirow{2}{*}{$\begin{array}{l}\text { Daya saing } \\
\text { perusahaan China } \\
\text { memasuki pasar } \\
\text { global }\end{array}$} \\
\hline Cash & & \\
\hline
\end{tabular}

\section{Gambar 1}

Empat Faktor Pendorong dan fase perkembangan Inovasi di China (Four Cs) (Sumber : Yip dan Mckern, 2015)

Belajar dari keberhasilan China dalam mengembangkan dan mendorong inovasi, dapat kita gambarkan kasus yang dialami oleh Pertamina dari kegagalan inovasi Pertamina dengan anak perusahaannya Petral dapat digambarkan sebagai berikut :

- Pelanggan (customer)

Ketika memasuki sebuah pasar, inovasi yang dilakukan dengan mengacu pada pemahaman yang mendalam terhadap pelanggan akan membuat kesuksesan dalam memasuki pasar yang besar dan dinamis. Kekuatan yang kuat ini mendasari pertumbuhan cepat dan intensitas persaingan perusahaan China. Pertamina melalui anak perusahaan Petral dalam tahapan awal berdiri pada fase perkembangan inovasi memiliki keinginan untuk memahami pelanggannya yaitu konsumen minyak di pasar dunia dengan menciptakan rantai pemasaran yang lebih efisien sehingga produk minyak mentah Indonesia dapat lebih mudah dipasarkan dan bersaing harga di pasar global. Dengan persaingan harga yang kompetitif akan meningkatkan penjualan dan 


\section{Wuryandari: " Kegagalan Inovasi Pertamina dalam Mengembangkan Rantai Supply Pemasaran dan ..."}

dapat meningkatkan pendapatan pertamina yang pada akhirnya adalah meningkatkan pendapatan negara. Pemahaman terhadap supply chain pemasaran produksi pertamina ini dapat menjadikan persaingan pertamina dengan negara lain lebih kompetitif serta lebih efisien, karena Pertamina lebih pro aktif dalam menjangkau salah satu pusat trading minyak dan gas bumi yaitu Singapura. Dalam hal memahami kebutuhan pelanggan, negara Singapura dapat dikatakan jauh lebih memahami kebutuhan konsumen dari negara-negara tetangganya, dimana meskipun Singapura tidak memiliki sumber daya minyak dan gas bumi, namun Singapura melihat momentum kebutuhan negara-negara tetangga dengan jumlah penduduk yang besar maka kebutuhan konsumsi terhadap BBM tentunya akan terus mengalami peningkatan. Singapura memanfaatkan peluang pasar tersebut dengan mendirikan kilang minyak yang memiliki kualitas terbaik di dunia yang kemudian menjadikan ketergantungan negara lain termasuk Indonesia terhadap Singapura untuk mendapatkan minyak yang telah siap menjadi bahan bakar minyak (BBM) untuk kebutuhan konsumsi dalam negeri. Pemahaman yang mendalam terhadap pelanggan menjadikan bukti kunci dalam keberhasilan sebuah inovasi.

- Budaya (culture)

Budaya disini tidak hanya mencakup dorongan kewirausahaan perusahaan namun juga adanya kepemimpinan serta dukungan Pemerintah. Belajar dari pengalaman China, dalam mendorong inovasi tidak hanya mendorong visi para pemimpin bisnis Cina, tetapi juga ambisi yang jelas dari pemerintah Cina untuk membuat Cina mandiri secara teknologi, diwujudkan melalui investasi berkelanjutan dalam penciptaan sistem inovasi nasional. Strategi besar pemerintah Cina dalam menciptakan ekosistem inovasi, bersama dengan strategi dukungan lainnya, telah sangat membantu perusahaan-perusahaan Cina untuk memenuhi kebutuhan pelanggan melalui inovasi. Hal ini yang tidak terjadi pada kasus Petral dan Pertamina, dimana Pemerintah Indonesia pada masa awal fase perkembangan Petral kurang memiliki visi yang jelas dalam penciptaan inovasi untuk menghasilkan system inovasi yang dapat membuat produksi minyak Indonesia berkompetisi di pasar global. Pemerintah Indonesia hanya melihat kecenderungan untuk pemenuhan kebutuhan jangka pendek dan menengah di mana tidak memanfaatkan momentum saat Pertamina memiliki pendapatan yang masih surplus dari hasil produksi minyak mentah dengan menciptakan kilang-kilang 
minyak baru di Indonesia. Dalam fase pertama pengembangan inovasi, factor customers dan culture ini menjadi landasan penting bagi perusahaan dalam kesuksesan sebuah inovasi yang dilakukan perusahaan. Kondisi tersebut anomaly apabila kita melihat kasus Petral, dimana politisasi yang kuat pada hampir semua kegiatan bisnis di masa Orde baru justu menjadikan sebuah terobosan yang dilakukan beberapa perusahaan BUMN dijadikan alat atau ditunggangi untuk kepentingan sekelompok golongan untuk mendapatkan keuntungan. Fungsi Pemerintah dalam pemanfaatan sumber daya alam dan mengusahakan kekayaan alam migas secara komersial justru menjadikan alat kepentingan sekelompok golongan. Kehadiran politik ini tidak hanya membentuk investasi produk tertentu yang teselubung dan kerugian perusahaan BUMN tetapi juga menciptakan peluang untuk korupsi. Budaya korupsi, kolusi dan nepotisme (KKN) Pemerintah orde baru pada saat itu akhirnya berdampak pada tidak efisennya terobosan yang dilakukan oleh Pertamina karena dukungan yang diberikan Pemerintah terhadap pemberantasan korupsi lemah. Hal inilah yang pada akhirnya membuat sebuah gagasan inovasi tidak berjalan dengan baik di tingkat implementasi karena factor budaya kepemimpinan dan dukungan pemerintah yang sangat lemah dimana budaya korupsi menjadi salah satu factor penting terjadinya pelemahan inovasi. Disamping itu, keinginan Pertamina pada awalnya untuk menjadi lebih kompetitif di pasar dunia juga tidak didukung dengan kuat karena masih rendahnya budaya kompetitif akibat persaingan monopoly Pertamina di pasar dalam negeri.

- $\quad$ Uang (cash)

Belajar dari perusahaan Cina, Ketika memasuki fase pertumbuhan ketiga dimana mereka melakukan transisi dari mencari sumber daya baru ke pengetahuan baru, Pemerintah Cina juga memberikan dukungan penuh membantu perusahaan local untuk menjadi sukses di pasar local dan mampu mengembangkan di pasar baru. Pengembangan inovasi membutuhkan dukungan keuangan/cash yang besar, dan lagilagi Pemerintah China tidak hanya mendorong perusahaan untuk gencar melakukan inovasi namun juga adanya perhatian dan dukungan terhadap kesulitan keuangan yang membuat inovasi China berkembang sangat pesar dalam dasawarsa terakhir. Faktor adanya dukungan dari Pemerintah dalam fase perkembangan ketiga (Cash) ini seringkali sulit dilakukan oleh Pemerintah Indonesia dalam pengembangan inovasi 


\section{Wuryandari: " Kegagalan Inovasi Pertamina dalam Mengembangkan Rantai Supply Pemasaran dan ..."}

yang dimiliki karena manajemen baik dari perusahaan dan pemerintah yang lemah, budaya kompetisi juga tidak kuat serta diperparah dengan budaya korupsi.

- Kemampuan perusahaan (capabilities)

Kemampuan Perusahaan (capabilities) merupakan factor penting yang harus dimiliki oleh perusahaan dalam mengembangkan inovasinya. Dukungan tidak hanya diperoleh dari perusahaan namun juga perlunya dukungan dari pemerintah. Dukungan Pemerintah terhadap kemampuan perusahaan dalam mengembangkan inovasi merupakan factor penting terhadap keberhasilan inovasi yang dilakukan perusahaan. Yip dan Mckern, 2015 menggambarkan pemerintah Cina telah menunjukkan tekad besar dalam menciptakan sistem inovasi nasional, di mana banyak perusahaan wirausaha merupakan penerima manfaat. Salah satu dukungan yang diberikan Pemerintah China adalah dukungan terhadap kemampuan perusahaan. Dukungan untuk mengembangkan kemampuan terutama pemahaman yang diberikan pelanggan, serta bagi perusahaan local yang tidak memiliki kemampuan seperti merek atau teknologi maka Pemerintah China memberikan dukungan keuangan/cash kepada perusahaan tersebut.

Belajar dari adanya factor pendorong inovasi di China dalam melewati fase-fase perkembangan inovasi yang pada akhirnya berkontribusi besar terhadap kemajuan pesat inovasi di China, Indonesia dapat belajar dari berbagai kegagalan inovasi yang telah dilakukan oleh perusahaan (dalam kasus ini adalah Petral) yang tidak saja membiarkan dan mendorong ide-ide inovasi bermunculan tapi perlu adanya komitmen dan campur tangan pemerintah yang besar dalam mendorong inovasi menjadi sebuah ide yang dapat sukses dan tembus di pasar yang dinamis. Kepemimpinan Pemerintah Indonesia dalam mendorong dan mengembangkan sebuah inovasi yang sukses juga harus kuat sebagai pemadu dalam permainan orchestra suatu kebijakan dalam mendorong inovasi. Leadership yang kuat juga harus melibatkan triple helix yaitu unsur Pemerintah, Industri, Akademisi sehingga akan dapat mendorong inovasi yang sukses di pasar. Dengan hilirisasi hasil riset Akademik akan dapat mempercepat pengembangan sebuah inovasi dalam pelaksanaan yang konsisten dan terarah. Disamping itu, konsistensi Pemerintah juga harus disertai dengan Langkah-langkah berani dalam memberantas korupsi yang seringkali praktek-praktek KKN menjadi penyebab pelemahan inovasi dalam tahapan implementasi di lapangan. Keterlibatan triple helix tersebut juga dengan komitmen 
Pemerintah yang kuat dapat memberikan efek kecepatan yang luar biasa dalam pengembangan inovasi seperti yang terjadi di China.

Keempat factor pendorong inovasi (Four $C s$ ) tidak berfungsi secara independen, namun merupakan interaksi antara elemen-elemen yang mendasarinya. Gambar berikut menunjukkan bagaimana tahapan pengembangan sebuah inovasi dengan 4 faktor pendorong yang dapat meningkatkan kemampuan perusahaan dalam menerapkan sebuah inovasi.

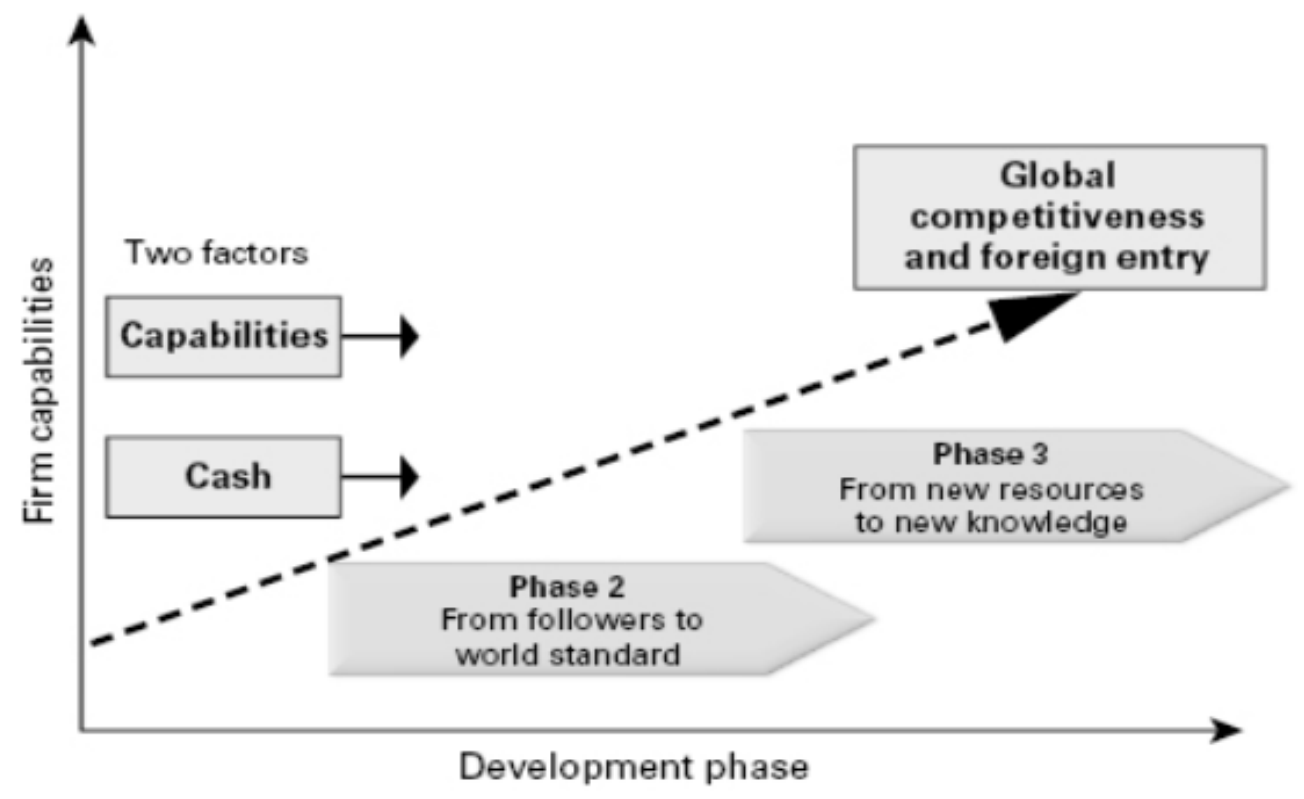

Gambar 2

Fase Perkembangan Inovasi di China

Sumber : Yip and Mckern, 2015

Pengalaman China dan belajar dari kegagalan Petral, dapat dikatakan Pertamina telah mengalami kegagalan inovasi dari fase perkembangan awal yaitu fase 1 dan 2 dimana pada akhirnya pemahaman mendalam terhadap konsumen ditinggalkan, serta tidak memikirkan peningkatan kebutuhan konsumen terhadap permintaan BBM dalam jangka panjang yang pada akhirnya berdampak pada pemborosan uang negara akibat perilaku pemburu rente/mafia migas. Factor budaya disini juga merupakan factor paling penting dan mendasar dari kegagalan Pertamina dimana masih tingginya budaya korupsi, rendahnya budaya kompetitif, serta rendahnya budaya dorongan kewirausahaan yang pada akhirnya hanya menguntungkan sekelompok golongan. Dukungan yang lemah 


\section{Wuryandari: " Kegagalan Inovasi Pertamina dalam Mengembangkan Rantai Supply Pemasaran dan ..."}

pemerintah terhadap inovasi juga menjadi salah satu penyebab utama kegagalan inovasi yang dilakukan Pertamina.

\section{Kesimpulan}

Berdasarkan dari uraian kasus dari kegagalan inovasi dan pengembangan usaha yang dilakukan oleh Pertamina melalui Petral dan anak perusahaannya, kita dapat memperoleh gambaran bahwa Indonesia dari dulu bahkan hingga saat ini masih mengalami kompleksitas masalah dari lingkaran keterpurukan dalam berbagai inovasi dan terobosan berbagai bidang. Kasim, Husaeni, Anwar dan Neo, 2015 mengidentifikasi sejumlah kompleksitas masalah yang dihadapi Indonesia yang menjadi penyebab keterpurukan dalam banyak hal termasuk mengembangkan inovasi baru antara lain: Pertama, budaya birokrasi menjadi penghambat kemajuan, seperti masih banyaknya nilai (values), keyakinan (beliefs), dan norma budaya yang kurang kondusif bagi upaya pembangunan. Budaya birokrasi Pemerintah ini dapat tercermin dari merosotnya nilai integritas (kejujuran), kurangnya meritokrasi (the best use of talent), perilaku yang sangat rule driven dari pada mission driven, kurang menghargai efisiensi , merosotnya nilai nasionalisme dan meningkatnya orientasi particularistic (seperti orientasi sukuisme, fanatisme agarama, dan perkoncoan), serta masih dominannya pola pikir linier dan mempertahankan status quo daripada pola pikir yang dinamis dan menginginkan perubahan yang menyeluruh. Penyebab kasus kegagalan Petral ini sangat menggambarkan kondisi tersebut. Kedua, administasi negara yang tidak responsif terhadap kebutuhan masyarakat, seperti prosedur pelayanan yang berbelit-belit, top-down approach tanpa adanya evaluasi program dan umpan balik. Kondisi ini juga diperparah dengan sistem pendidikan nasional yang lemah, tidak mampu menghasilkan lulusan yang berkualiatas sebagai knowledge workers yang inovatif sebagai penggerak pembangunan nasional. Hal tersebut menjadi salah satu penyebab kerjasama dalam bentuk triple helix (Pemerintah, Industri dan Akademik) menjadi sulit dilakukan dengan baik.

Indonesia dapat belajar dari China dalam mendorong inovasi yang dapat membuat lonjakan inovasi begitu pesat di China dengan memperhatikan factor-faktor pendorong dan bagaimana konsisitensi dan dukungan pemerintah yang besar dalam proses tahapan inovasi seperti yang telah diuraikan dalam pembahasan penulisan. Dalam meniru keberhasilan China dan juga kejelian dan kecermatan Singapura dalam inovasi 
membangun kilang minyak berkualitas tinggi untuk mensuplai konsumsi energi bahan bakar minyak negara-negara tetangga, diperlukan tindakan yang cepat dan penuh semangat dalam mencapai tujuan dimana kepemimpinan transformasional (Vision, integrity, trust, selflessness, commitment, creative ability, toughness, communication, risk taking, dan visibility) menjadi salah satu factor kunci dalam melakukan perubahan secara cepat dan radikal tersebut (Kasim, Husaeni, Anwar dan Neo, 2015). Adanya kepemimpinan transformasional dengan keputusan strategis yang berperan sebagai pengungkit perubahan yang radikal, dapat menciptakan kerangka dynamic governance yang diperlukan demi efektivitas administrasi pemerintah. Dynamic Governance yang diterapkan pada pemerintahan di Singapura mengandung 3 unsur yang sangat diperlukan terhadap berjalannya Pemerintahan yang inovatif (Neo dan Chen, 2007) yaitu :

- Berfikir kedepan (thinking ahead) yaitu kemampuan untuk memprediksi kemungkinan perkembangan di masa depan yang mampu mempengaruhi eksistensi suatu negara,

- Berfikir kembali (thinking again) yaitu kemampuan atau keinginan untuk memikirkan kembali fungsi dari kebijakan, apakah mampu mempengaruhi kinerja atau tidak,

- Berfikir jernih (thinking across) yaitu kemampuan dan keterbukaan atas batasan dengan belajar dari pengalaman orang lain sehingga mampu menciptakan ide dan konsep baru.

Belajar dari kegagalan berdasarkan kasus Petral, dapat diuraikan bahwa budaya merupakan fondasi mendasar dalam pemerintahan yang dinamis serta mendasari dalam berbagai bidang dalam terobosan-terobosan yang dilakukan oleh Pemerintah. Budaya merupakan seperangkat nilai, kepercayaan, dan prinsip sebagai pegangan dalam kehidupan bermasyarakat dimana budaya pada akhirnya akan menjadi penentu dalam proses perumusan kebijakan dan agenda. Budaya dan norma kemudian yang akan berperan sebagai bahan pertimbangan dalam mengadopsi atau mengadaptasi sebuah kebijakan baru. Selanjutnya, budaya dan norma pula yang akan menjadi sebuah katalisator dalam proses pengambilan keputusan. Kegagalan Pertamina melalui Petral kita dapat belajar, dimana budaya dan kepemimpinan transformasional yang kemudian akan membawa kepada dukungan Pemerintah terhadap inovasi sebuah perusahaan, 


\section{Wuryandari: " Kegagalan Inovasi Pertamina dalam Mengembangkan Rantai Supply Pemasaran dan ..."}

merupakan factor kunci yang akan membawa perubahan dan pengembangan inovasi dalam berbagai bidang di Indonesia.

\section{Daftar Pustaka}

Arvirianty, Anastasia.(2019).Disorot KPK, Begini Modus Mafia Migas Rampok APBN di

Petral. dalam https://www.cnbcindonesia.com/news/20190910123931-498306/disorot-kpk-begini-modus-mafia-migas-rampok-apbn-di-petral.10 September 2019.

Basri, Faisal dkk (2015). Rekomendasi Akhir: Memperkokoh Kelembagaan Sektor Migas Indonesia. Tim Reformasi Tata Kelola Migas (TRTKM), Kementerian Energi dan Sumber Daya Mineral (ESDM).

Budiartie, Gustidha .(2019). Singapura Tak Punya Minyak Tapi Punya Kilang, Udah Gila!. dalam https://www.cnbcindonesia.com/news/20191213114442-4122814/singapura-tak-punya-minyak-tapi-punya-kilang-udah-gila.13

December 2019.

Burmansyah, E., Nasution, Ade Parlaungan (2015). Analisis Ketergantungan Impor BBM dari Singapura dan Kegagalan Batam dalam Proses Industrialisasi. www.journal.unrika.ac.id

Castellion, George., Markham, Stephen K. (2012). Perspective: New Product Failure Rates: Influence of Argumentum ad Populum and Self-Interest. J Prod Innov Manag 2013;30(5):976-979 (C) 2012 Product Development \& Management Association. DOI: 10.1111/j.1540-5885.2012.01009.x

Daniel, Katherine. A., Coombes, Peter. J., White, Ian (2014). Politics of Innovation in Multi-level Water Governance Systems. Journal of Hydrology 519 (2014) 24152435. Journal homepage: www.elsevier.com/locate/jhydrol

Drucker, Peter. F, (1996). Inovasi dan Kewiraswastaan yang diterjemahkan oleh Rusjdi Naib. Jakarta (ID): Erlangga.

Kasim, Azhar., Huseini, Martani., Anwar, Rozan., Neo, Boon Siong. (2015). Merekonstruksi Indonesia: Sebuah Perjalanan Menuju Dynamic Governance. Penerbit Buku Kompas 
Kirshner, Samuel Nathan., Levin, Yuri., Nediak, Mikhail. (2017). Product Upgrades with Stochastic Technology Advancement, Product Failure, and Brand Commitment. Production and Operations Management 26(4), pp. 742-756

Neo, Boon Siong., Geraldine Chen (2007). Dynamic Governance - Embedding Culture, Capabilities, and Change in Singapura. World Scientific Publishing Co. Pte. Ltd.

Okezone. (2018). Kebijakan Sukses Jokowi, Mulai dari Pembubaran Petral hingga Penurunan Tingkat Kemiskinan. dalam https://economy.okezone.com/read/2018/10/29/320/1970275/kebijakan-suksesjokowi-mulai-dari-pembubaran-petral-hingga-penurunan-tingkatkemiskinan.Senin 29 Oktober 2018

Sutisna, Joshua Adhikara., Huseini, Martani (2019). Dua factor Penentu Keberhasilan Sebuah Proses Inovasi. Jurnal Inovasi Bisnis 7 (2018) 1-7. Website: www.ejournal.polbeng.ac.id/index.php/IBP

Suryowati, Estu. Editor Josephus Primus. Purnatugas, Tim Anti-mafia Migas Berikan 12 Rekomendasi ke Pemerintah. (2015). dalam https://money.kompas.com/read/2015/05/13/205618226/Purnatugas.Tim.Antimafia.Migas.Berikan.12.Rekomendasi.ke.Pemerintah?page=all.13/05/2015

Yip, George S., Mckern, Bruce (2015). China's Nexr Strategic Advantage From Imitation to Innovation. The MIT Press Cambridge, Massachusetts, London, England. 